\title{
The effect of the type of roughage in the diet on plasma cholesterol levels and aortic atherosis in rabbits
}

\author{
By J. H. MOORE* \\ National Institute for Research in Dairying, Shinfield, Reading
}

(Received 25 fuly 1966-Accepted 22 September 1966)

\begin{abstract}
1. Eleven groups of male rabbits (eight to eleven per group) were given ad lib. a diet consisting of 61 parts of a low-fat basal ration to which were added: for groups $1-3,20$ parts maize oil ; for groups 4-7, 20 parts butterfat; and for groups 8-I I, 0.47 parts maize oil and 43 . 1 parts wheat starch. Different types of roughage were added to the 61 parts of basal ration as follows: for groups $I, 4$ and 8, I9 parts ground wheat straw; for groups 2, 5 and 9, I9 parts Solkafloc; for groups 3,6 and 10, 19 parts of shredded cellophane; and for groups 7 and 1 I, 14 parts shredded cellophane and 5 parts peat.

2. After the rabbits had been given the experimental diets for a period of 40 weeks, the plasma cholesterol levels were determined. The animals were then killed and the degree of atheromatous degeneration was determined after the aortas had been stained with Sudan IV.

3. Elevated levels of plasma cholesterol and extensive atheromatous degeneration were observed in the rabbits given the diets containing $20 \%$ butterfat (groups $4-7$ ) and in those given the diets containing $48 \%$ starch (groups 8-1 1 ). Lower levels of plasma cholesterol and only slight atheromatous degeneration were observed in the rabbits given the diets containing $20 \%$ maize oil (groups $\mathrm{I}-3$ ).

4. The levels of plasma cholesterol and the degree of aortic atherosis were influenced very markedly by the nature of the dietary roughage. Plasma cholesterol levels and degrees of aortic atherosis tended to be higher when cellophane was the roughage component than when wheat straw was the roughage component of the diet. The replacement of part of the cellophane of the diet by peat reduced the level of plasma cholesterol and the degree of aortic atherosis.

5. The possible mechanisms by which the nature of the dietary roughage influences plasma cholesterol levels are discussed.
\end{abstract}

Funch, Krogh \& Dam (1960) gave rabbits for 42 weeks a diet containing $20 \%$ butterfat and observed that the mean concentration of cholesterol in the serum during the last 20 weeks of the experiment was $65^{8} \mathrm{mg} / 100 \mathrm{ml}$. In a similar experiment Moore \& Williams ( I 964) gave rabbits for 38 weeks a diet containing $20 \%$ butterfat but found that the mean concentration of cholesterol in the plasma during the last 20 weeks of the experiment was only $140 \mathrm{mg} / \mathrm{I} 00 \mathrm{ml}$. It was also clear that the degree of aortic atherosis observed by Funch et al. (1960) in rabbits given the diet containing $20 \%$ butterfat was considerably greater than that observed by Moore \& Williams (I964) in rabbits given a similar diet for a similar period. In these two investigations (Funch et al. 1960; Moore \& Williams, I964) the general experimental procedures and the compositions of the semi-purified basal diets, although not identical, were similar, as were the ages and weights of the rabbits at the beginning of the experiments and the gains in weight during the experiments. One possible explanation of the discrepancy in these results is that the rabbits used by Funch et al. (I960) were more susceptible to the dietary induction of hypercholesterolaemia and aortic atherosis than were the animals used by Moore \& Williams (1964). Some evidence that different strains of rabbit respond

* Present address: Hannah Dairy Research Institute, Ayr, Scotland. 
differently to atherogenic diets has in fact been obtained by Moore \& Williams (1966). Nevertheless, the experimental diets used by Funch et al. (1960) and Moore \& Williams (1964) did differ in one respect-Funch et al. (I960) used a purified form of cellulose as a source of roughage in their experimental diets whereas Moore \& Williams (I964) used finely ground wheat straw. This seemingly minor difference in the experimental diets at first appeared to have little bearing on the discrepancy in the results but subsequent preliminary experiments in our laboratory suggested that the nature of the dietary roughage could modify the atherogenic and hypocholesterolaemic effects of a particular diet. Briefly, these preliminary experiments were as follows.

Two groups of rabbits (twelve animals per group) were given for 40 weeks a diet containing $20 \%$ butterfat and $19 \%$ shredded cellophane (as roughage). The rabbits in one group were housed in the older type of wooden hutches in which peat was used as litter whereas the animals in the other group were housed in metal metabolism cages in which no litter was used. During the experiment it was observed that the rabbits in the wooden hutches ate a certain amount of the peat. At the end of the experiment the degrees of hypercholesterolaemia and aortic atherosis in the rabbits housed in the metal cages were far greater than in the animals housed in the wooden hutches. Further, the degrees of hypercholesterolaemia and atherosis in the rabbits housed in the metal cages and given the butterfat-cellophane diet were considerably greater than had been observed previously by Moore \& Williams (I964) in rabbits housed in similar metal cages but given a diet containing $20 \%$ butterfat and $19 \%$ wheat straw. These preliminary observations led to a more detailed investigation of the effects of different types of roughage in the diet on the development of hypercholesterolaemia and aortic atherosis in the rabbit. The types of roughage studied were finely ground wheat straw, a purified form of cellulose (Solkafloc), shredded cellophane and peat. 'I 'he results of this investigation are now reported.

\section{EXPERIMENTAL}

\section{Rabbits, diets and procedure}

The rabbits used in this study were 132 New Zealand White males, all of the same strain, obtained at the age of 6 months from a local breeder. The animals were housed in individual metal metabolism cages fitted with wire screens which obviated the use of litter during the experiment. For a short period until they became accustomed to their surroundings the animals were given a commercial rabbit diet. The rabbits were then randomly divided into eleven groups of twelve each and were given the various experimental diets for a period of 40 weeks Throughout the experiment food and water were given ad lib.

The basal diet was similar to that described by Moore \& Williams (1964) and consisted (parts by weight) of wheat starch (Starch Products Ltd, Slough) 16.3, sucrose I0.0, casein (lactic acid casein; Glaxo Research Ltd, Greenford) $25^{\circ}$, methyl cellulose (Celacol M. 45०; J. M. Steel and Co. Ltd, London, WC 2) I.0, potassium acetate 2.5 , magnesium oxide 0.5 , sodium chloride 0.7 , choline chloride 0.5 , salt mixture 4.0 and vitamin mixture 0.5 , making $6 \mathrm{I}$ parts in all. The compositions of the salt and 
vitamin mixtures have been given by Moore \& Williams (1964). To 6r parts of this low-fat basal diet were added: for group 1,20 parts maize oil and 19 parts wheat straw (ground to pass through a $2 \mathrm{~mm}$ sieve); for group 2, 20 parts maize oil and 19 parts Solkafloc (Grade BW 40; Johnsen, Jorgensen and Wettre Ltd, London, EC 4); for group 3, 20 parts maize oil and I9 parts shredded cellophane (cellophane spangles; British Cellophane Ltd, Bridgwater, Somerset); for group 4, 20 parts butterfat (prepared as described by Moore \& Williams, 1964) and 19 parts wheat straw; for group 5, 20 parts butterfat and I9 parts Solkafloc; for group 6, 20 parts butterfat and I9 parts shredded cellophane; for group 7, 20 parts butterfat, I 4 parts shredded cellophane and 5 parts peat; for group 8, 0.47 parts maize oil, 43.1 parts wheat starch and I9 parts wheat straw; for group 9, 0.47 parts maize oil, 43. I parts wheat starch and I9 parts Solkafloc; for group Io, 0.47 parts maize oil, 43.1 parts wheat starch and I9 parts shredded cellophane; and for group $11,0.47$ parts maize oil, $43^{\cdot}$ I parts wheat

Table I. Experimental diets: additions (parts by weight) of maize oil, butterfat or starch and different types of roughage to 61 parts of the low-fat basal diet for each dietary treatment

\begin{tabular}{|c|c|c|c|c|c|c|c|}
\hline $\begin{array}{c}\text { Group } \\
\text { no. }\end{array}$ & $\begin{array}{l}\text { Maize } \\
\text { oil }\end{array}$ & $\begin{array}{c}\text { Butter- } \\
\text { fat }\end{array}$ & $\begin{array}{l}\text { Wheat } \\
\text { starch }\end{array}$ & $\begin{array}{l}\text { Wheat } \\
\text { straw }\end{array}$ & Solkafloc & $\begin{array}{l}\text { Shredded } \\
\text { cellophane }\end{array}$ & Peat \\
\hline I & 20 & - & - & 19 & - & - & - \\
\hline 2 & 20 & - & - & - & 19 & - & - \\
\hline 3 & 20 & - & 一 & 一 & - & 19 & - \\
\hline 4 & - & 20 & - & I 9 & - & - & - \\
\hline 5 & - & 20 & - & - & 19 & - & - \\
\hline 6 & - & 20 & - & - & - & 19 & - \\
\hline 7 & -- & 20 & - & - & - & 14 & 5 \\
\hline 8 & 0.47 & - & $43^{-I}$ & 19 & - & - & - \\
\hline 9 & 0.47 & - & $43^{-x}$ & 一 & 19 & 一 & - \\
\hline 10 & 0.47 & - & $43 \cdot I$ & - & - & 19 & - \\
\hline II & 0.47 & $\cdots$ & $43 \cdot I$ & - & - & 14 & 5 \\
\hline
\end{tabular}

starch, 14 parts shredded cellophane and 5 parts peat. These additions to 6I parts of the low-fat basal diet for each dietary treatment are summarized in Table I. It should be noted that none of the diets was supplemented with cholesterol. Gas chromatographic analysis showed that the percentages of linoleic acid in the maize oil and butterfat used in this experiment were 53.0 and 1.26 respectively. Thus $20 \mathrm{~g}$ of butterfat and a mixture of $0.47 \mathrm{~g}$ maize oil and $43 . \mathrm{I} \mathrm{g}$ wheat starch each supplied $0.25 \mathrm{~g}$ linoleic acid and $186.6 \mathrm{kcal}$ gross energy. Therefore, the linoleic acid:gross energy ratios of the diets given to the rabbits in groups $4^{-7}$ were the same as those of the diets given to the rabbits in groups 8-I I. Analysis of samples of wheat straw, Solkafloc, shredded cellophane and peat revealed that all these dietary components contained less than $0.02 \%$ linoleic acid. The animals were given the experimental diets in the form of pellets prepared as described previously (Moore \& Williams, 1964).

During the experiment, the weights of individual rabbits and the total weights of food consumed by the various groups of rabbits were recorded. Unfortunately, the design of the rabbit cages and food containers did not allow accurate measurement of the food intake of individual rabbits. After 40 weeks on the experimental diets, samples 
of blood were taken from the marginal ear veins of the rabbits and immediately afterwards the animals were killed by a blow on the head. As rapidly as possible thereafter, the aorta, extending from the heart to the point of division into the two common iliac arteries, was removed from each rabbit. Blood samples were collected in heparinized tubes.

Treatment of tissues and methods of analysis. After the removal of adventitious fatty tissues, the aortas were fixed in $4 \%(\mathrm{w} / \mathrm{v})$ formaldehyde in $0.9 \%(\mathrm{w} / \mathrm{v})$ sodium chloride saturated with calcium carbonate. Each aorta was then stained with Sudan IV (0.05\%, $\mathrm{w} / \mathrm{v}$, in ethanol-acetone-water, $35: 35: 30, \mathrm{v} / \mathrm{v} / \mathrm{v}$ ). With a standard atheromatous aorta for comparison, the degree of atheromatous degeneration of each aorta was assessed by the technique reported by Moore \& Williams (1964). The concentration of total cholesterol in the samples of blood plasma was determined by a combination of the methods of Abell, Levy, Brodie \& Kendall (1952) and Brown (1959) as described by Moore \& Williams (1964).

\section{RESULTS}

During the experiment one rabbit died in each of groups $2,4,8$ and 9 , two in each of groups 5 and 7 , three in each of groups 3, 6 and I I and four in each of groups $I$ and ro. Post-mortem examinations at the local Veterinary Investigation Centre of the Ministry of Agriculture, Fisheries and Food revealed that deaths were caused either by 'middle-ear' disease, pneumonia or enteritis. The gains in weight of the animals auring the experiment were broadly similar in all groups (Table 2) and the small differences that did occur between treatments did not appear to be attributable to variations in the major sources of energy (i.e. maize oil, butterfat or starch) or to variations in the type of roughage in the experimental diets. The daily dry-matter intakes during the experiment (Table 2) were similar (about $97 \mathrm{~g} / \mathrm{rabbit}$ ) for the animals in groups $\mathrm{I}-7$ given the diets containing $20 \%$ fat. The daily dry-matter intakes were also similar (about $1 \mathrm{I} 8 \mathrm{~g} / \mathrm{rabbit}$ ) for the animals in groups 8-r given the highcarbohydrate diets. The gross energy values of the high-fat diets (groups $1-7$ ) and high-carbohydrate diets (groups 8-II) were about 532 and $427 \mathrm{kcal} / \mathrm{I} 00 \mathrm{~g}$ diet respectively. Thus it may be calculated that the daily gross energy intakes in all groups were between 505 and $515 \mathrm{kcal} / \mathrm{rabbit}$. This finding is consistent with the observed similarity in the increases in weight of the animals on the various dietary treatments during the experiment.

The results given in Table 2 show that the plasma cholesterol levels of the rabbits given the diets containing $20 \%$ maize oil (groups $\mathrm{I}-3$ ) were consistently lower than those of the rabbits given the diets containing $20 \%$ butterfat (groups $4-7$ ). This confirms the results reported previously from our laboratory (Moore \& Kon, I963; Moore \& Williams, 1964) and from the laboratories of other investigators (Lambert, Miller, Olsen \& Frost, 1958; Wigand, 1959; Funch et al. 1960; Gottenbos \&'Thomasson 196r). However, the plasma cholesterol levels of the rabbits in group 2 (given the diet containing maize oil and Solkafloc) and group 3 (given the diet containing maize oil and cellophane) were considerably higher than the plasma cholesterol levels of the rabbits in group I (given the diet containing maize oil and wheat straw). Although the 
concentration of plasma cholesterol in the rabbits of group 3 appeared to be somewhat higher than that in the rabbits of group 2, the difference was small. A similar, but not identical pattern of variation in plasma cholesterol level with the type of roughage in the diet was observed in the animals given the diets containing $20 \%$ butterfat (groups 4-6). The concentration of cholesterol in the plasma of the rabbits in group 6 (given the diet containing cellophane) was markedly higher than the concentration of cholesterol in the plasma of the rabbits in group 4 (given the diet containing wheat straw) and group 5 (given the diet containing Solkafloc). On the other hand, the

Table 2. Weights of rabbits at the beginning and end of the experiment, daily drymatter intake during the experiment, and concentrations of plasma cholesterol and degrees of aortic atherosis at the end of the experiment

\begin{tabular}{|c|c|c|c|c|c|c|c|}
\hline $\begin{array}{c}\text { Group } \\
\text { no. }\end{array}$ & Diet & $\begin{array}{l}\text { No./ } \\
\text { group } \\
\text { at end } \\
\text { of } \\
\text { experi- } \\
\text { ment }\end{array}$ & $\begin{array}{c}\text { Weight* } \\
\text { (kg) at } \\
\text { beginning of } \\
\text { experiment }\end{array}$ & $\begin{array}{l}\text { Weight* } \\
(\mathrm{kg}) \text { at } \\
\text { end of } \\
\text { experiment }\end{array}$ & $\begin{array}{l}\text { Daily } \\
\text { dry- } \\
\text { matter } \\
\text { intake } \\
\text { (g) }\end{array}$ & $\begin{array}{c}\text { Plasma } \\
\text { cholesterol } \\
\text { level* } \\
(\mathrm{mg} / \mathrm{ro0} \mathrm{ml})\end{array}$ & $\begin{array}{c}\text { Degrees } \dagger \\
\text { of aortic } \\
\text { atherosis }\end{array}$ \\
\hline I & $\begin{array}{l}\text { Maize oil, wheat } \\
\text { straw }\end{array}$ & 8 & $3.15 \pm 0.19$ & $3.65 \pm 0.20$ & 95 & $23.4 \pm 4.0$ & $0.7 \pm 0.61$ \\
\hline 2 & $\begin{array}{l}\text { Maize oil } \\
\text { Solkafloc }\end{array}$ & I I & $3 \cdot 42 \pm 0.13$ & $3 \cdot 88 \pm 0 \cdot 1 \mathrm{I}$ & 98 & $60 \cdot 5 \pm 4 \cdot 9$ & $x \cdot 3 \pm 0.25$ \\
\hline 3 & $\begin{array}{l}\text { Maize oil, } \\
\text { cellophane }\end{array}$ & 9 & $3.23 \pm 0.14$ & $3.68 \pm 0.14$ & 96 & $7 x \cdot 3 \pm 5 \cdot 5$ & $5.0 \pm 0.66$ \\
\hline 4 & $\begin{array}{l}\text { Butterfat, } \\
\text { wheat straw }\end{array}$ & I I & $3.57 \pm 0.15$ & $4.03 \pm 0.24$ & 97 & I $14 \pm$ II 9 & $12 \cdot 7 \pm 3 \cdot 0$ \\
\hline 5 & $\begin{array}{l}\text { Butterfat, } \\
\text { Solkafloc }\end{array}$ & 10 & $3.40 \pm 0.09$ & $3 \cdot 89 \pm 0 \cdot 13$ & 97 & $133 \pm 9 \cdot 6$ & $20 \cdot 8 \pm 2 \cdot 9$ \\
\hline 6 & $\begin{array}{l}\text { Butterfat, } \\
\text { cellophane }\end{array}$ & 9 & $3 \cdot 34 \pm 0.111$ & $3 \cdot 80 \pm 0.12$ & 96 & $216 \pm 13 \cdot 7$ & $37 \cdot 5 \pm 6 \cdot 8$ \\
\hline 7 & $\begin{array}{l}\text { Butterfat, } \\
\text { cellophane, peat }\end{array}$ & ro & $3.30 \pm 0.18$ & $3 \cdot 77 \pm 0.23$ & 98 & $I 4 I \pm 12 \cdot 4$ & $10 \cdot 7 \pm 2 \cdot 0$ \\
\hline 8 & $\begin{array}{l}\text { Starch, wheat } \\
\text { straw }\end{array}$ & I I & $3.41 \pm 0.09$ & $3.94 \pm 0.19$ & II 8 & $8 I \cdot 4 \pm 10 \cdot 2$ & $9 \cdot 5 \pm I \cdot 6$ \\
\hline 9 & $\begin{array}{l}\text { Starch, } \\
\text { Solkafloc }\end{array}$ & I I & $3.20 \pm 0.13$ & $3 \cdot 63 \pm 0.19$ & II9 & I $18 \pm 8 \cdot 5$ & $\mathrm{I} 2 \cdot 0 \pm \mathrm{I} \cdot 8$ \\
\hline 10 & $\begin{array}{l}\text { Starch, } \\
\text { cellophane }\end{array}$ & 8 & $3.27 \pm 0.17$ & $3 * 77 \pm 0 \cdot 16$ & I 16 & $172 \pm 11 \cdot 4$ & $25 \cdot 1 \pm 3 \cdot 4$ \\
\hline I I & $\begin{array}{l}\text { Starch, } \\
\text { cellophane, peat }\end{array}$ & 9 & $3.40 \pm 0.18$ & $3.88 \pm 0.20$ & 120 & $103 \pm 8 \cdot 4$ & $7 \cdot 3 \pm 1 \cdot 7$ \\
\hline
\end{tabular}

difference in plasma cholesterol concentration between groups 4 and 5 was relatively small. Comparison of the results for groups 6 and 7 showed that the replacement of 5 parts of cellophane in the diet by 5 parts of peat (Table $\mathrm{I}$ ) resulted in a noticeably lower level of cholesterol in the plasma of the rabbits in group 7 . The same trend in the relationship between plasma cholesterol levels and the type of roughage in the diet was evident in the rabbits of groups 8-I I given the high-starch diets. The plasma cholesterol concentration in the rabbits of group ro was higher than that in the rabbits of group 9 and the plasma cholesterol concentration in the rabbits in group 9 was in turn higher than that in the rabbits in group 8 . Comparison of the results for groups ro and I again showed that the replacement of part of the dietary cellophane by peat 
(Table I) gave rise to a lower concentration of plasma cholesterol in the rabbits of group II.

In agreement with previous findings (Moore \& Williams, 1964) the degrees of aortic atherosis in the rabbits given the butterfat diets (groups 4-7) or the high-starch diets (groups 8-II) were considerably higher than in the rabbits given the diets containing $20 \%$ maize oil (groups $\mathrm{I}-3$ ). The degree of aortic atherosis was particularly low in the rabbits given the diet containing maize oil and wheat straw (group I) but was somewhat higher in the rabbits given the diets containing maize oil and Solkafloc (group 2) or maize oil and cellophane (group 3). In the rabbits of group 6 (given the diet containing butterfat and cellophane) the degree of aortic atherosis was much greater than that in the rabbits of group 5 (given the diet containing butterfat and Solkafloc) and the degree of aortic atherosis in the rabbits of group 5 was in turn greater than that in the rabbits of group 4 (given the diet containing butterfat and wheat straw). When the results for groups 6 and 7 are compared it is clear that the replacement of part of the cellophane in the diet by peat reduced the degree of aortic atherosis in the rabbits of group 7 to a level that was similar to that observed in the rabbits of group 4. The degree of aortic atherosis in the rabbits of group ro was considerably greater than that in the rabbits of groups 8,9 and I I.

As noted previously (Moore \& Williams, 1964 ) the results in Table 2 indicated that there was no simple relationship between the degree of hypercholesterolaemia and the degree of aortic atherosis in the experimental rabbits. For instance, the plasma cholesterol levels in groups 5 and 7 were very similar yet the degree of aortic atherosis in the rabbits of group 5 was about twice that in the rabbits of group 7. Again, the plasma cholesterol concentrations in groups 3 and 8 were very similar but the degree of aortic atherosis in the rabbits of group 8 was almost twice that in the rabbits of group 3 .

\section{DISCUSSION}

During the last ${ }_{5} 5$ years or so there has been intensive research into the relationships between the composition of the diet, the concentrations of lipids in the blood and atheromatous degeneration of the aorta and coronary arteries in man and various experimental animals. Although the effects of the type and level of fat in the diet on blood lipids and cardiovascular degeneration have perhaps received most attention (e.g. see reviews by Portman \& Stare, I959; Wigand, I959; Olson, I960; Olson \& Vester, 1960) it is clear that other components of the diet are also involved. For instance, it has been shown that the type and level of carbohydrate (Nichols, Gofman \& Dobbin, 1956; Nichols, Dobbin \& Gofman, 1957; Ahrens, 1957; Grant \& Fahrenbach, 1957, 1959; Gofman, 1958; Nath, Harper \& Elvehjem, 1959a; Wells \& Anderson, 1959; Guggenheim, Ilan \& Peretz, 1960) and protein and amino acids (Mann, Andrus, McNally \& Stare, 1953; Fillios \& Mann, 1954; Shapiro \& Freedman, 1955; Fillios, Andrus, Mann \& Stare, 1956; Johnson, Leveille \& Fisher, 1958; Fisher, Feigenbaum, Leveille, Weiss \& Griminger, 1959; Nath, Harper \& Elvehjem, I959 $b$; Kokatnur, Rand \& Kummerow, I958; Mann, I960) in the diet exert a considerable influence on the concentration of the various lipid fractions in the blood. Other dietary components that have been implicated in the control of blood lipid 
levels are nicotinic acid (Miller, Hamilton \& Goldsmith, 1960), pyridoxine (Dam, Kristensen, Nielsen \& Søndergaard, I958), pantothenic acid (Boyd, 1953), iron (Siperstein, Nichols \& Chaikoff, 1953), cobalt (Tennent, Mushett, Kuron, Ott \& Siegal, 1958), magnesium and calcium (Vitale, White, Nakamura, Hegsted, Zamcheck \& Hellerstein, 1957). It is thus apparent that the relationships between the composition of the diet, the concentration of blood lipids and the atheromatous degeneration of arterial tissues are extremely complex. Nevertheless, it was somewhat surprising to find that the nature of the roughage, a seemingly innocuous component of the diet, should have such a pronounced influence on the concentration of cholesterol in the plasma and on the degree of aortic atherosis in the experimental rabbits. This finding and the observation that separate strains of rabbits show marked differences in their susceptibilities to the dietary induction of hypercholesterolemia and atherosis (Moore \& Williams, 1966) offer some explanation for the discrepancies between the results obtained previously in our laboratory (Moore \& Williams, 1964) and those obtained by Funch et al. (1960). Kritchevsky (1964) has drawn attention to the fact that, whereas certain investigators have been able to induce aortic atherosis in rabbits by giving the animals semi-synthetic diets supplemented with saturated fat, other investigators have observed little or no aortic atherosis in rabbits given commercial or stock diets supplemented with saturated fat. The results of the experiment now reported may have some bearing on these discrepancies.

At present it is difficult to put forward any mechanism that could account for the observed effects of variations in the type of dietary roughage on the level of cholesterol in the plasma of the experimental rabbits. Little is known about the extent to which various forms of roughage are digested by rabbits. Some forms of roughage may be digested more readily than others and it is possible, but perhaps rather unlikely, that after absorption from the intestine the products of digestion may then inhibit or promote the synthesis, transport or degradation of cholesterol in the tissues of the rabbit. A more likely explanation of the observed effects of roughage on plasma cholesterol levels would appear to involve some interaction in the lumen of the gastrointestinal tract between cholesterol, bile acids and the indigestible food residues. Cholesterol is degraded to bile acids in the liver and the process of elimination of cholesterol involves the secretion in the bile of cholesterol and bile acids. The extent to which the endogenous cholesterol and bile acids are reabsorbed from the lower small intestine is thought to play a considerable part in the control of blood cholesterol levels. For instance, Siperstein et al. (1953) have shown that the addition of $3 \%$ ferric chloride to the diet of cockerels reduced the concentration of plasma cholesterol and the incidence of aortic atherosis. Siperstein et al. (1953) concluded that this reduction in plasma cholesterol was due to the fact that the reabsorption of bile acids was prevented by the precipitation of the bile acids by iron in the intestinal tract. Bergen, Van Itallie, Tennent \& Sebrell (1959) observed a $20 \%$ decrease in the serum cholesterol when MK I 35 (an anion exchange resin with a marked affinity for bile acids) was administered orally to human patients with hypercholesterolaemia. Eyssen, Evrard, Vanderhaeghe \& De Somer (1965) have shown that in chicks the hypocholesterolaemic effect of dietary $\mathrm{N}$-acetylated neomycin (which has no antibiotic activity) is associated 
with a ninefold increase in the excretion of chenodeoxycholic acid in the droppings. $N$-acetylated neomycin forms a precipitate with bile acids in vitro (Eyssen et al. 1965). It would seem reasonable to suppose, therefore, that any dietary constituent that precipitates, absorbs or adsorbs cholesterol or bile acids will cause a break in the entero-hepatic circulation of these lipids and will thus exert some controlling influence on blood cholesterol levels. In this connexion it is important to note that the excretion of sterols and bile acids in the faeces of rats is increased when the level of fibre in the diet is increased (Coleman \& Baumann, 1957; Portman, Mann \& Wysocki, 1955). Walker \& Arvidsson (1954) and Bersohn, Walker \& Higginson (1956) have suggested that there might be a relationship between the low serum cholesterol levels and the high fibre content of the diet of the Bantu. In the experiments now reported, the same level of roughage was included in the diets given, for instance, to the rabbits in groups 3-7 (Table I). The question now arises whether endogenous cholesterol or bile acids in the lumen of the intestinal tract were absorbed or adsorbed more readily by ground wheat straw or peat than by cellophane or Solkafloc. This question cannot be answered until an investigation has been made of the excretion of bile acids and sterols in the faeces of rabbits given different types of dietary roughage.

The author gratefully acknowledges the encouragement given by Professor S. K. Kon and thanks Miss J. Carrinci, Mr E. V. Ruby and Mr G. Quelch for skilled technical assistance. This study was supported by a grant from the Butter Information Council.

\section{REFERENCES}

Abell, L. L., Levy, B. B., Brodie, B. B. \& Kendall, F. E. (1952). F. biol. Chem. 195, 357. Ahrens, E. H. Jr (1957). Am. F. Med. 23, 928.

Bergen, S. S. Jr, Van Itallie, T. B., Tennent, D. M. \& Sebrell, W. H. (1959). Proc. Soc. exp. Biol. Med. 102, 676.

Bersohn, I., Walker, A. R. P. \& Higginson, J. (1956). S. Afr. med. F. 30, $4 \mathrm{I}$ I.

Boyd, G. S. (1953). Biochem. F. 55, 892 .

Brown, W. D. (1959). Aust. F. exp. Biol. med. Sci. 37, 523.

Coleman, D. L. \& Baumanr, C. A. (1957). Archs Biochem. Biophys. 66, 226.

Dam, H., Kristensen, G., Nielsen, G. K. \& Søndergaard, E. (I958). Acta physiol. scand. $44,67$.

Eyssen, H. Evrard, E., Vanderhaeghe, H. \& De Somer, P. (1965). Tijdschr. Gastroent. 8, I 21.

Fillios, L. C., Andrus, S. B., Mann, G. V. \& Stare, F. J. (1956). F. exp. Med. ro4, 539.

Fillios, L. C. \& Mann, S. V. (1954). Metabolism 3, I6.

Fisher, H., Feigenbaum, A., Leveille, G. A., Weiss, H. S. \& Griminger, P. (1959). F. Nutr. 69, I 63.

Funch, J. P., Krogh, B. \& Dam, H. (1960). Br. F. Nutr. 14, 355.

Gofman, J. W. (1958). Am. F. Cardiol. I, 27 I.

Gottenbos, J. J. \& Thomasson, H. J. ( ( 961). Colloques int. natn. Rech. scient. no. 99, p. 22 I.

Grant, W. C. \& Fahrenbach, M. J. (1957). Fedn Proc. Fedn Am. Socs exp. Biol. r6, 50.

Grant, W. C. \& Fahrenbach, M. J. (1959). Proc. Soc. exp. Biol. Med. roo, 250.

Guggenheim, K., Ilan, J. \& Peretz, E. (1960). F. Nutr. 72, 93.

Johnson, D. Jr, Leveille, G. A. \& Fisher, H. (1958). F. Nutr. 66, 367.

Kokatnur, M., Rand, N. T. \& Kummerow, F. A. (1958). Circulation Res. 6, 424.

Kritchevsky, D. (1964). F. Atheroscler. Res. 4, 103.

Lambert, G. F., Miller, J. P. Olsen, R. T. \& Frost, D. V. (1958). Proc. Soc. exp. Biol. Med. 97, 544. Mann, G. V. (1960). Am. F. clin. Nutr. 8, 49 I.

Mann, G. V., Andrus, S. B., McNally, A. \& Stare, F. J. (1953). F. exp. Med. 98, 195.

Miller, O. N., Hamilton, J. G. \& Goldsmith, G. A. (1960). Am. F. clin. Nutr. 8, 480.

Moore, J. H. \& Kon, S. K. (1963). Chemy Ind. p. 165.

Moore, J. H. \& Williams, D. L. (1964). Br. F. Nutr. 18, 253.

Moore, J. H. \& Williams, D. L. (1966). Br. F. Nutr. 20, 57 r.

Nath, N. Harper, A. E. \& Elvehjem, C. A. (1959a). Proc. Soc. exp. Biol. Med. 102, 57 I. 
Nath, N. Harper; A. E. \& Eivehjem, C. A. (1959b). Can. F. Biochem. Physiol. 37, 1375.

Nichols, A. V., Dobbin, V. \& Gofman, J. W. (I957). Geriatrics 12, 7.

Nichols, A. V., Gofman, J. W. \& Dobbin, V. (1956). Lancet ii, I2 I I.

Olson, R. E. (1960). Circulation 22, 29.

Olson, R. E. \& Vester, J. W. (1960). Physiol. Rev. 40, 677.

Portman, O. W., Mann, G. V. \& Wysocki, A. P. (1955). Archs Biochem. Biophys. 59, 224.

Portman, O. W. \& Stare, F. J. (I959). Physiol. Rev. 39, 407.

Shapiro, S. L. \& Freedman, L. (1955). Am. F. Physiol. r8r, 44I.

Siperstein, M. D., Nichols, C. W. Jr, \& Chaikoff, I. L. (1953). Science, N. Y. 117, 386.

Tennent, D. M., Mushett, C. W., Kuron, G. W., Ott, W. H. \& Siegal, H. (1958). Proc. Soc. exp. Biol. Med. 98, 474 .

Vitale, J. J., White, P. L., Nakamura, M., Hegsted, D. M., Zamcheck, N. \& Hellerstein, E. E. (I957). F. exp. Med. ro6, 757 .

Walker, A. R. P. \& Arvidsson, U. B. (1954). F. clin Invest. 33, $135^{8}$.

Wells, W. W. \& Anderson, S. C. (1959). F. Nutr. 68, 541.

Wigand, G. (1959). Acta med. scand. I66, Suppl. 35 I. 